\title{
MONETARY AND FOREIGN CURRENCY POLICY OF THE EUROPEAN CENTRAL BANK
}

\author{
Vladimir Mladenovićc ${ }^{1,}{ }^{*}$, Miroljub Hadžić ${ }^{2}$ \\ ${ }^{1}$ Business School of Applied Studies Blace, \\ 70 Kralja Petra I, Blace, Serbia \\ ${ }^{2}$ Singidunum University, Department of Business \\ 32 Danijelova Street, Belgrade, Serbia
}

\begin{abstract}
:
The paper analyzes how successful the ECB has been in pursuing its monetary and foreign exchange policy, which is, at the same time, a complex issue and crucial for the justification of its existence. Firstly, the ECB is trying hard to keep up with the global crisis and to maintain the stability of the euro. The main task of the ECB is to keep inflation below $2 \%$ p.a. This paper demonstrates that the ECB has managed to retain inflation within the required limits for a significant period of time, except for few relatively short-lived exceptions. By managing an adequate monetary policy the ECB has successfully accomplished its goals in the period of reference, as demonstrated by inflation trend results, monetary aggregate M3, and the level of interest rates.
\end{abstract}

\author{
Key words: \\ monetary policy, \\ European Central Bank, \\ inflation, \\ interest rates, \\ euro.
}

\section{EUROPEAN CENTRAL BANK AND ITS INDEPENDENCE}

The European Central Bank was established on June 1, 1998. Along with national central banks of 17 members of the European Monetary Union (Eurozone) and central banks of other EU members, it constituted the ESCB (European System of Central Banks). The main task of the ECB was to manage operations related to the introduction of a common currency - the euro, and to supervise the whole process. According to the Maastricht Agreement, the ESCB is the cornerstone of monetary power of EU, which defines monetary aggregates, monetary policy and implements monetary instruments. Some authors argued (Bernholz, 1999, p. 777) that the decision to leave national central banks within the ESCB could be linked to some aspects of the monetary policy management and the decentralization issue on one hand and, on the other hand, the reten- tion of present positions within the ESCB and the efficiency of such a monetary policy management.

In the past, central banks were seen as institutions capable and responsible to fulfill several goals at the same time: providing the high rate of economic growth and employment, financing state budget and coping with balance of payment problems. In line with this, economic theory did not comment on the independence of central banks and credibility of their monetary policies. Today, the independence of central banks is higher than before and their primary goal is price stability (Cukierman, 2007, p. 368). The Independence of a central bank is understood as the existence of high level of freedom in the creation and realization of monetary policy. However, the independence of central bank is a rather wider concept: personal independence, financial independence and independence in monetary policy (independence in formulation of the goal and independence in monetary instruments introduction) (Barjaktarović, 2010, p. 167). 
According to the Maastricht Convention, the ECB is in charge of maintaining stable prices, as well as preserving the stability of output and employment rates. In order to achieve these goals, the ECB built up a wall to protect itself from the interference of politics (Grauwe, 2005, p. 176). The independence of the ECB is closely related to its main goal - price stability. The concept of independence of the ECB consists of: institutional independence, legal independence, functional and operational independence, financial and organizational independence (Scheller, 2006, p. 124).

The ECB only recognizes the aim of the monetary policy. This is laid down by the Maastricht Convention which, at the same time, empowers the ECB to pursue other goals, provided that they do not undermine price stability (Grauwe, 2005, p. 207). Price stability can be understood as the situation with neither inflation nor deflation in the long run (Gerdesmeier, 2011, p. 24). Price stability was firstly defined in 1998 by Supervisory board of the ECB as annual HICP (Harmonized Index of Consumer Prices) bellow 2\%, in medium period. It was slightly changed in 2003 into: annual inflation rate under, but near to $2 \%$, in medium term (European Central Bank, 2011, p. 65).

\section{MONETARY POLICY}

The monetary policy and policy of public finances are the most important components of macroeconomic policy. Monetary policy's function is to regulate the amount of money in circulation, maintain the balance between commodity stocks and monetary funds, enable smooth performance of commodity circulation, and ensure a stable economic course.

Monetary-credit policy relies on certain categories - monetary indicators, which are used in the definition of the quality and the function of money in economy, as well as in management of the monetary policy and the solvency policy in economy and other sectors. These indicators actually constitute the basis for an efficient monetary policy, since they are used as the means for controlling its effects, in the first place its basic orientation and its adjustment to current economic trends. They are called monetary aggregates (Barać et al., 2007, p. 59).

Monetary policy involves the mastering and conscious directing (i.e. control) of all forms and flows of money in reproduction (solvent, insolvent, foreign currency, and other funds). Credit policy in- volves an active participation of the banking system in the regulation of credit volume and its structure in economy. Active influence on one of the main channels of the creation and withdrawal of money in circulation, as well as on credit volume involves detailed and carefully crafted actions through which a predominant portion of money in economy is determined. Therefore, the two concepts merge into one, namely the monetary-credit policy, since operations are not exclusively "monetary" or "credit", although there is a commonly held view that the current money is basically credit(deposit) money (Barać et al., 2007, p. 58).

Central banks usually use three main monetary instruments:

- Open market operations - supply or withdrawal of state securities;

- Rate of refinancing - interest rate by which central banks are ready to finance commercial banks, within national economy, in the short run;

- Compulsory reserves - part of deposits collected within commercial banks, which has to be unused for credit lending (Mankiw and Taylor, 2011, p. 600).

Strategy of ECB monetary policy is based on:

- Quantitative definition of the price stability (inflation rate below, but near to $2 \%$ annually, in the medium run) and

- Two anchor approach for the examination of price stability risk:

- Firstly, economic analysis of factors which determine prices in short and medium run and

- Secondly, monetary analysis of the relation between money supply and prices in long run (Gerdesmeier, 2011, p. 63).

\section{FOREIGN CURRENCY POLICY}

The system of economic relations with foreign markets, as an important part of the economic system, should provide conditions for a rational integration of the national economy into the international division of labor. This primarily means that systemic instruments will provide an objective assessment of cost-effective engagement of production factors in individual economic activities and, consequently, the identification of sectors in which a national economy makes the most of available resources (Jovanović Gavrilović, 2008, pp. 23-24). 
The price at which one national currency is exchanged for another is called foreign currency rate. Foreign currency rate should be distinguished from foreign currency parity which represents an officially established value of the national money, expressed through a more widely accepted denominator, such as: gold, special drawing rights (SDR), a more stable and important national currency, etc. Under normal circumstances foreign currency rate is close to foreign currency parity as it constitutes its basis (Jovanović Gavrilović, 2008, pp. 23-24).

\section{EUROPEAN CENTRAL BANK AND THE GLOBAL ECONOMIC CRISIS}

The global economic crisis, and the crisis of international financial markets, that occurred in the second half of 2007, raised numerous questions about the financial stability of the Eurozone. Despite the crisis, the financial system of the Eurozone remained relatively robust and resistant in 2007. Prior to the market crisis the financial system of the Eurozone had been in a good financial position, owing to strong profitability of the banking sector that lasted for a few years. Thus, the banking system was quite secure from risks. Enhanced profitability of large banks of the euro area in 2007 was largely driven by a strong increase in non-interest income. Besides, the degree of profitability was also related to a (low) degree of collection of bad debts.

In the course of 2008, tensions and problems in the financial system of the Eurozone occurred, and gradually only deteriorated. As months went by, commercial banks of the euro were experiencing a decline in market capitalization, due to a fall in share price, a decrease in the loans volume, and an increase in credit expenses. As the uncertainty, caused by global economic developments, was mounting, aversion to risks, felt by the participants in the financial market, was growing. Credit market solvency deteriorated and the availability of funds fell during the year, while the activity of insurance markets slowed down. In such an environment, investors and creditors started to lose confidence into the ability of some financial companies to meet their obligations. Consequently, a lot of major financial companies encountered challenges, trying to access funds and capital markets. Some of the largest financial institutions experienced a decline in the price of their shares at the stock market. Due to such a development, some international institutions were forced to ask for an additional support from the governments. However, bankruptcy was inevitable for some international financial institutions. Initially, commercial banks in the Eurozone faced the financial crisis from a generally stable financial position (which at the time did not cause any concern), owing to several years of positive (profitable) operations. Although some large banks were affected by depreciation that continued persistently for a year, they seemed to be resistant to unfavorable developments until the dramatic downturn in September 2008.

In 2009, the ECB Council adopted supplementary non-standard measures, as it was facing dysfunctional money markets, despite relatively low ECB's key interest rates and low interest rates on loans. It was also expected that support for the recovery would be given through the lowering of interest rates for households and businesses. These actions surpassed the outcome which could have been achieved through the reduction of the ECB key interest rates. This approach took into account the fact that, in the Eurozone, banks play the major role in providing financial resources for the real economy. As a result, the terms of financing improved substantially, and this reduced tensions on the money market. All the non-standard actions, adopted by the Council, were temporary and designed to maintain price stability for the time being, in a direct and an indirect way, while inflation expectations remained firmly anchored, owing to price stability.

Monetary policy, implemented in 2010, led to the start of recovery of the euro area while, on the other hand, tensions on financial markets lingered. The Recovery of the real economy in 2010 appeared to be stronger than expected. Still, heightened financial tensions recurred in May. These events could be treated as a result of growing concern over the monetary sphere, given the (un)sustainability of the public finance policy (especially in Greece), since it produces adverse effects on other countries and economies, particularly on the government bonds market.

In 2011, the European Central Bank continued to be a firm and reliable support, as confirmed by the fact that the expected mid- to long-term inflation was stable and close to $2 \%$ but still below this level. In 2011, a general rise in prices directly stemmed from higher prices of energy and assets, resulting in an immediate inflation rise. 
The set of measures, announced and adopted by the ECB Council and high representatives of member states of the Eurozone, referred to several key areas, their aim having been to restore the financial stability of the euro. Key elements of the new set of measures refer to new fiscal measures and more effective tools for stabilizing the Eurozone, including the more efficient financial stability, faster implementation of the Stabilization Program mechanism, and measures for tackling problems in Greece. In Greece, Ireland, and Portugal tensions on the government bonds market diminished but in the meantime spread to Italy and Spain and, subsequently, to other countries of the euro area. Such developments were also reflected in other issues, such as financial sustainability in certain countries of the Eurozone, concerns about global economic prospects, insecurity as to the financial support extended by the EU to member states of the euro area that were most vulnerable to the debt crisis, alongside the possibility of engaging the private sector in this area.

According to the analysis of general economic and monetary trends for 2012, inflation remained at an acceptable level and in pace with the long-term goal. This is confirmed by the cross-analysis of signals coming from the monetary sphere. Additional economic policy measures and the progress of European reforms can help sustain the financial sentiment on the market and enhance the opportunities for economic growth.

\section{MAIN FEATURES OF THE ECB MONETARY AND FOREIGN CURRENCY POLICY IN THE PERIOD 2004-2012}

The ECB instruments and their effects and results, monetary-credit features and foreign currency policy for the period 2004-2012 have been analysed so as to reach valid conclusions with regard to the ECB economic policy measures.

\section{Monetary aggregate $\mathrm{M} 3$}

The total solvency assets (M3) is a wider aggregate than M2 and it consists of: solvency assets (M2), reserve assets, assets for the payment of orders from abroad, assets for covering the letters of credit, other limited deposits, assets for the purchase of foreign currency, and joint assets.

Monetary dynamics (currency in circulation), within the European monetary union, in 2004, was under the influence of two opposed forces: on one hand, there were low interest rates and, on the other hand, the normalization of the contraction of debts and investment of citizens, stemming from their current situation, in the period from 2001 to mid-2003.

A stronger monetary growth was perceived in 2005 , owing to the stimulative effect of low interest rates within the Eurozone. At the same time, discouraging growth effects of M3 (as presented in Graph 1), related to stabilized investment activity of the Eurozone citizens, were losing its pace, especially in the first half of the year. In a nutshell, accelerated monetary growth in 2005 spurred further monetary growth in the euro area.

In 2006, monetary growth continued, reaching, at the end of the year, the highest ever annual rate, since the beginning of EMU Phase 3. The Strong growth of M3 was largely a product of low levels of interest rates and more vigorous economic activity in the euro area, further propped up by a strong expansion of credits extended to the private sector.

\begin{tabular}{lcccc}
\hline \multicolumn{1}{c}{ Liabilities } & $\mathrm{M} 1$ & $\mathrm{M} 2$ & $\mathrm{M} 3$ \\
\hline Money in circulation & $\mathrm{X}$ & $\mathrm{X}$ & $\mathrm{X}$ \\
\hline Overnight deposits & $\mathrm{X}$ & $\mathrm{X}$ & $\mathrm{X}$ \\
\hline Deposits with agreed maturity of up to 2 years & & $\mathrm{X}$ & $\mathrm{X}$ \\
\hline Deposits redeemable at notice of up to 3 months & $\mathrm{X}$ & $\mathrm{X}$ \\
\hline Repurchaseagreement & & & $\mathrm{X}$ \\
\hline Money market funds shares/units & & $\mathrm{X}$ \\
\hline Debt securities issued with a maturity of up to 2 years & & $\mathrm{X}$ \\
\hline
\end{tabular}

Table 1: Monetary aggregates definition in Eurozone

Source: http://www.ecb.europa.eu/mopo/strategy/monan/html/index.en.html 


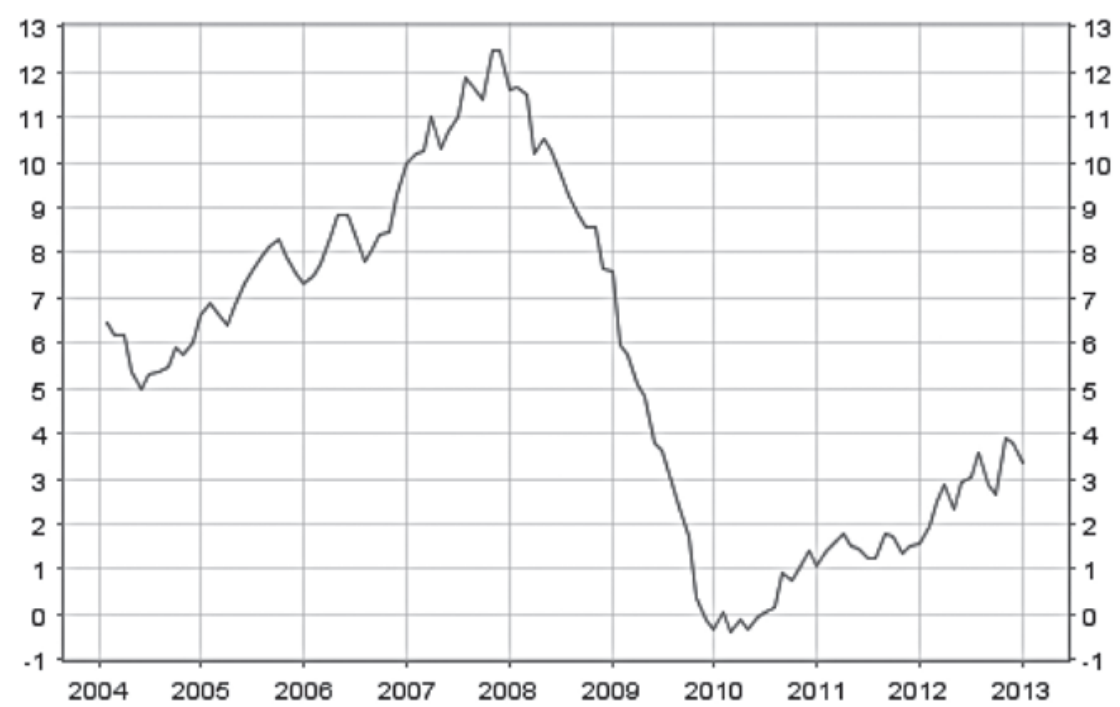

Graph 1: EU M3 trends in the period 2004-2012

Source: http://sdw.ecb.europa.eu/home.do?chart=t.1.2

The wide basis of the monetary trends analysis suggests that the growth of M3 to some extent can excessively increase the rate of monetary expansion. Strong M3 growth can be guided by the theoretical requirements of monetary values.

A crucial turn of events, with regard to monetary trends, came with the global economic crisis in 2008 when it started, and especially at the beginning of 2009. Monetary expansion was moderate during 2008. The rough estimation of M3 components confirmed the existence of monetary growth, which was moderate at the time. Throughout the year, the growth of non-financial private sector loans slowed down, following the introduction of tighter borrowing requirements and a weaker economic activity.

In 2009, the annual growth rate of M3 and loans to the private sector slipped into the negative zone. Economic recession, i.e. subdued production and trade, as well as uncertainty of business prospects, continued to push back companies' demand for financial resources. To a certain extent, a lack of financial resources, extended by banks, also played an important role, as stated by analysts of bank loans in the euro zone.

The growth of M3 was moderate in 2010, at an average rate of $0.6 \%$. This serves to confirm the assessment that monetary expansion was moderate and inflation pressures around the mid-year limited. By that time, the monetary analysis used as the basis for the analysis and the assessment of money supply and credit growth, had been improved mark- edly. This only reinforced the ECB's mid-term monetary policy strategy.

The ECB's monetary policy took a new turn in 2011. Monetary expansion, from the years prior to the crisis, continued, the underlying objective having been to help economic activities recover and come out of the recession zone. After a relatively low growth of M3 of 1.7\% in 2010, monetary expansion in the euro area gradually accelerated in the first three quarters of 2011, reaching 2.9\% in September 2011 (as it can be seen in Figure 2). Still, financial market tensions and the pressure exerted on banks to adjust their annual balance sheets, particularly in the field of capital needs, undermined monetary dynamics in the autumn and slowed down the overall annual growth rate, reducing it to $1.5 \%$ in December. The profile of M3 growth in 2011 was under a strong impact of inter-banking transactions. Therefore, it can be concluded that monetary expansion throughout the year was moderate.

The annual rate of $\mathrm{M} 3$ rose to $3.9 \%$ in October 2012, from 2.6\% in September, while the growth of M1 sped up to $6.4 \%$, from $5.0 \%$ a month earlier. These trends, partially down to a specific nature of the business, led to higher overnight deposits which belong to the non-monetary financial sector. Household and non-financial corporation deposits increased in October.

To sum up, the period under consideration can be divided into three sub-periods that were characterized by different profiles of the monetary policy 
and the money supply, as measured by the monetary aggregate M3. During the period of escalation of the global economy crisis, 2008 inclusive, the monetary policy was moderately expansive. In the following period, 2010 inclusive, monetary restriction was introduced in order to suppress inflation pressures, with a subsequent revival of the monetary expansion whose aim was to lead to the overcoming of economic recession in the Eurozone.

\section{Inflation}

One of the main tasks of the ECB is to keep inflation at the level of up to $2 \%$. The ECB has striven to reach that goal by pursuing an adequate monetary policy, and thus alleviate the impact of the global economic crisis and maintain stability.

The inflation rate in 2004 was, to a great extent, driven by an increase in administrative prices and indirect fees and, in the second half of the year in particular, a higher price of oil. Out of these reasons, the annual HICP (Harmonized Index of Consumer Prices) inflation in 2004 remained at the same level, compared to the level of $2.1 \%$, of the year before (European Central Bank, 2005, p. 43).

Long-term inflation expectations remained at a level similar to the one associated with price stability. Inflation in 2005 was slightly faster, mostly due to the rising trend of energy prices and, to a limited extent, the increase in administrative prices and in- direct fees. The annual inflation was kept at an acceptable level of $2.2 \%$ in 2005 .

An average annual rate of price increase reached $2.2 \%$ in 2006, almost the same level as in 2005, which can be seen in Graph 2. The inflation rate was unstable throughout the year and it was mostly affected by changes in the price of oil.

Annual inflation remained at $2.1 \%$ in 2007 as well. The inflation rate was quite unstable, just like the year before, due to the impact of energy prices. At the end of the year, the annual inflation went up sharply to much above $2 \%$. The increase was largely caused by rising oil and food prices in the second half of 2007.

In 2008, a relatively high inflation trend continued from the end of the previous year, due to large-scale effects of the crisis and the atmosphere of instability and strong inflationary expectations. An average annual inflation rate in 2008 rose to as much as $3.3 \%$, considerably above the level the ECB had aspired to on a long-term basis; moreover, this was the highest level ever since the introduction of the euro. Under the influence of a restrictive ECB monetary policy, inflation pressures fell to $1.6 \%$ in December.

In 2009 , the annual inflation rate first dropped from $1.1 \%$ in January, to $-0.7 \%$ in July, before it sped up again to $0.9 \%$ in December. Major factors, that caused oscillations to the general price increase, were the increase in production prices and in prices of energy resources.

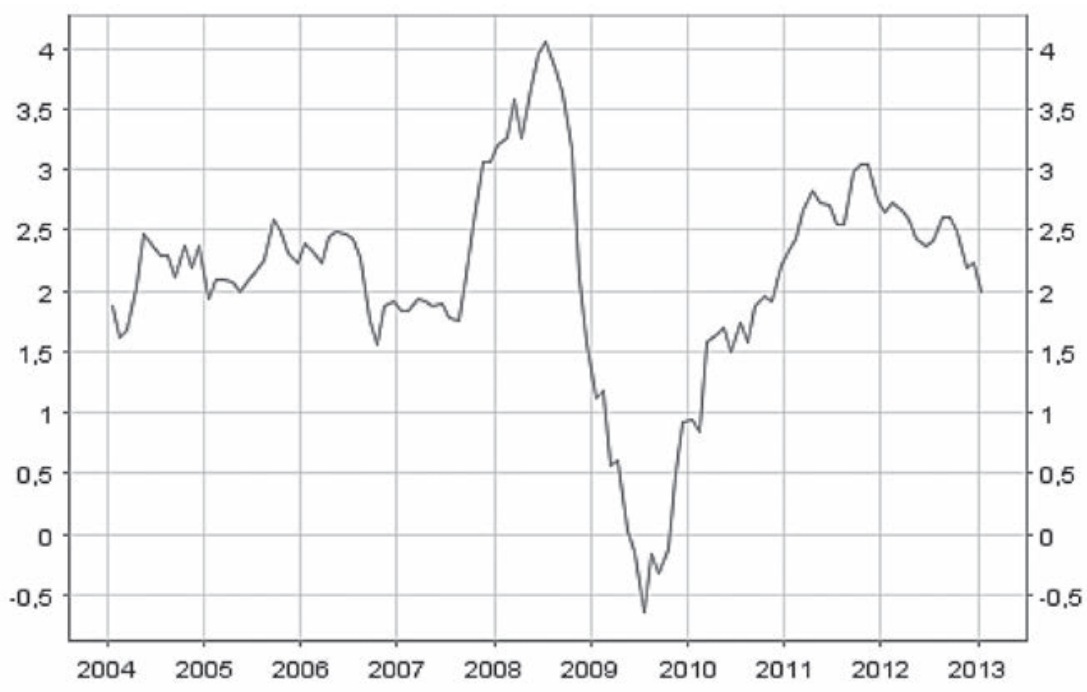

Graph 2: EMU Inflation rate in the period 2004 - 2012

Source: $h t t p: / / s d w . e c b . e u r o p a . e u / h o m e . d o ? c h a r t=t .1 .1$ 
Inflationary pressures lessened in the course of 2010 , primarily owing to a shift in the monetary policy toward monetary restriction in 2009, which resulted in an average annual inflation rate of $1.6 \%$ only.

In 2011, inflation was constantly at a higher level, on average at $2.7 \%$, as an effect of a restored monetary expansion that was designed to help the real economy overcome recession. As for the monthly profile of annual inflation, it gradually rose from $2.3 \%$ in January, to the maximum of $3.0 \%$ in the period from September to November, dropping again to $2.7 \%$ in December. Mid-term and long-term expectations, as regards inflation, remained steadily at the targeted ECB levels.

According to Eurostat data, annual inflation dropped to an acceptable level of $2.2 \%$ in November 2012. On the basis of current prices of oil futures, a further fall to below $2 \%$ is expected in 2013. By means of the policy relevant to the horizon, and under conditions of weak economic activity in the Eurozone, and well-anchored long-term inflationary expectations, price pressures will probably remain rather moderate.

\section{Interest rates}

The interest rate, set by the Governors Council, presents the minimal tender rate, beyond which the European Central Bank would not accept offers submitted by financial institutions (Grauwe, 2005, p. 318).
The ECB Council kept key interest rates unchanged during 2004, and that at historically low levels. The lowest offered rate of ECB major refinancing operations was kept at $2 \%$, while the rates of deposit facilities and marginal facilities of lending remained at $1 \%$ and $3 \%$, respectively.

In 2006, the Council raised the key interest rates, in order to curb the risk of strong inflation pressures that had been detected. Monetary adjustment took place under conditions of economic growth and powerful money and credit expansion. In a series of expansion developments, the Council raised the minimal offered rate of major refinancing operations of the euro-system from $2.25 \%$ in January, to $3.50 \%$ by the end of 2006 .

The Council continued the adjustment of the monetary policy, by raising the key interest rates by 50 index points in March and June, and so the minimal offered rates were increased to $4.00 \%$ in June 2007.

When the global economic crisis escalated, the Council started the monetary relaxation, by lowering the reference interest rates. Firstly, it reduced the rate of the major refinancing operation by 150 base points, to $1 \%$, and that in four stages. In May, it decided to lower it to $1.75 \%$, leaving the interest rate on deposit facilities at the same level, of 0.25.

Considering the effects of monetary relaxation, the ECB Council came to a conclusion that the profile of interest rates policy should not be altered

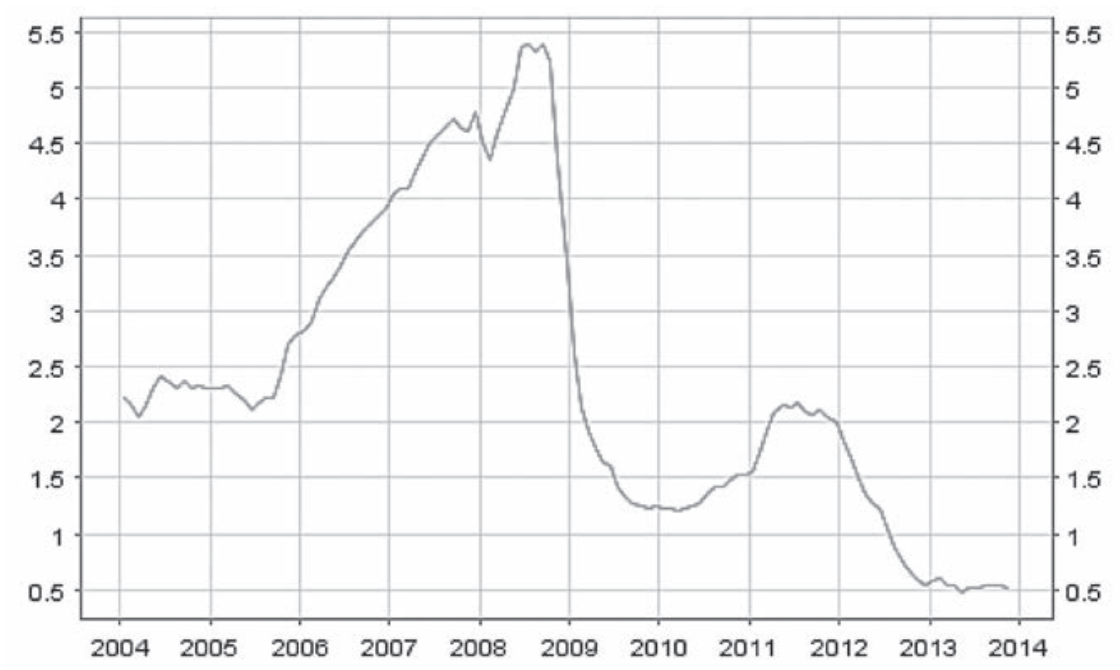

Graph 3: EMU Interest rates on the money market in the period 2004 - 2011 (\% p.a.)

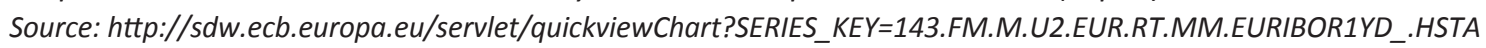


and, accordingly, left the key ECB interest rates at an unchanged, historically low level, reached in May 2009. The interest rate on major refinancing operations was at $1.00 \%$ during 2010 , the rate on deposit facilities at $0.25 \%$, and the rate on the marginal interest facility at $1.75 \%$.

In 2011, the interest rate policy was slightly modified. In order to secure and maintain stability, the ECB Council raised basic interest rates in April and July 2011, by 25 percentage points each time.

\section{CONCLUSION}

The paper pointed out that independent position of a central bank is essentially important for a successful monetary policy. There are several important elements which ensure independency of the ECB to political influences, such as: institutional independence, legal independence, functional and operational independence, financial and organizational independence. Increasing interest in the (in)dependency of a central bank, in recent years, is the result of increasing interest in joining the Eurozone. At the same time, economic theory argued that there is a positive relationship between independent position of a central bank and price stability. The paper also found out that ECB monetary policy was successful, because the main aim of the policy and analytical tools were well defined. As it was pointed, the price stability was defined as inflation rate below, but near to $2 \%$ annually. Also, price stability risk was well assessed using both: economic analysis, in short and medium run, and monetary analysis in long run.

The ECB's task is to keep inflation under control, at the level of $2 \%$. By managing an adequate monetary policy, the ECB has striven to reach its goal and thus reduce the impact of the world economic crisis and maintain stability. The proof that the task was successfully fulfilled, i.e. that inflation remained below $2 \%$, is the fact that the ECB managed to keep inflation around $2 \%$, for a long time. Aberrant situations, when inflation exceeded the $2 \%$ target, were relatively short (in 2008 inflation was at 3.3\%, during 2009 somewhat higher). After these short-lived episodes inflation would go back to within the targeted range.

Through regular monitoring of monetary aggregates, the ECB managed to track the situation, in terms of the required amount of the circulating money, and to timely decide on corrective measures of monetary regulation, for the largest part of the analyzed period. During the period of the global economic crisis escalation (2008 inclusive), monetary policy was moderately expansive. What ensued in the next period (2010 inclusive), was monetary restriction, the main objective of which was the curbing of inflation pressures. In the period that followed, monetary expansion was revivified, for the purpose of overcoming the economic crisis in the Eurozone.

An adequate policy of reference interest rates was an efficient lever of monetary regulation. The analysis of the monetary policy profile and its basic instruments, including interest rates, and the analysis of achieved results in the pursuit of the desired goal - price stability, confirm that inflation will be within the target of below $2 \%$, if the reference interest rate is regulated at $2 \%$.

The dynamic analysis of the monetary policy, and results achieved during years of work, demonstrate that the ECB has led an adequate monetary policy, which resulted in a successful accomplishment of its objectives, for the most of the period analyzed, including the period of the economic crisis escalation.

\section{REFERENCES}

Barać, S., Stakić, B., Hadžić, M., \& Ivaniš, M. (2007). Praktikum za bankarsko poslovanje. Beograd: Fakultet za finansijski menadžment i osiguranje. (in Serbian).

Barjaktarović, L. (2010). Monetarno - kreditni i devizni sistem. Beograd: Univerzitet Singidunum. (in Serbian).

Bernholz, P. (1999). The Bundesbank and the process of European monetary integration. In: Fifty years of the Deutsche Mark: Central Bank and the currency in Germany since 1948. Oxford: Oxford University Press.

Cukierman, A. (2007). Nezavisnost centralne banke i institucije monetarne politike: prošlost, sadašnjost i budućnost. Paneconomicus, 54(4), 367-395. (in Serbian). doi:10.2298/PAN0704367C.

European Central Bank. (2005). Annual Report 2004. Retrieved March 10, 2013, from http://www.ecb.europa. eu/pub/pdf/annrep/ar2004en.pdf.

European Central Bank. (2006). Annual Report 2005. Retrieved March 10, 2013, from http://www.ecb.int/pub/ pdf/annrep/ar2005en.pdf.

European Central Bank. (2007). Annual Report 2006. Retrieved March 10, 2013, from http://www.ecb.int/pub/ pdf/annrep/ar2006en.pdf.

European Central Bank. (2008). Annual Report 2007. Retrieved March 10, 2013, from http://www.ecb.int/pub/ pdf/annrep/ar2007en.pdf. 
European Central Bank. (2009). Annual Report 2008. Retrieved March 10, 2013, from http://www.ecb.int/pub/ pdf/annrep/ar2008en.pdf.

European Central Bank. (2010). Annual Report 2009. Retrieved March 10, 2013, from http://www.ecb.int/pub/ pdf/annrep/ar2009en.pdf.

European Central Bank. (2011). Annual Report 2010. Retrieved March 10, 2013, from http:// www.ecb.int/pub/ pdf/annrep/ar2010en.pdf.

European Central Bank. (2012). Annual Report 2011. Retrieved March 10, 2013, from http://www.ecb.int/pub/ pdf/annrep/ar2011en.pdf.

European Central Bank. (2011). The monetary policy of the $E C B$. Frankfurt am Main: European Central Bank.
Gerdesmeier, D. (2011). Price stability: Why is it importnat to you? Retrieved March 10, 2013, from http:// www.ecb.europa.eu/pub/pdf/other/whypricestability_en.pdf.

Grauwe, P. (2005). Economics of monetary union. Oxford: Oxford University Press.

Jovanović Gavrilović, P. (2008). Međunarodno poslovno finansiranje. Beograd: Centar za izdavačku delatnost Ekonomskog fakulteta. (in Serbian).

Mankiw, N.G., \& Taylor, M.P. (2011). Economics. Andover: Cengage Learning.

Scheller, H.K. (2006). The European Central Bank: History, role and functions. Frankfurt: European Central Bank.

\section{MONETARNA I DEVIZNA POLITIKA EVROPSKE CENTRALNE BANKE}

\section{Rezime:}

Ovaj rad se bavi analizom uspešnosti Evropske centralne banke u sprovođenju svoje monetarne i devizne politike, što je, istovremeno, jedan kompleksan zadatak, od vitalnog značaja za opravdanost njenog postojanja. ECB, najpre, ulaže velike napore da ide u korak sa svetskom krizom i da očuva stabilnost evra. Osnovni zadatak Evropske centralne banke jeste da inflaciju zadrži ispod 2\%, na godišnjem nivou. Ovaj rad pokazuje da je ECB uspela da održi inflaciju u traženim okvirima, tokom značajnog vremenskog perioda, sa nekoliko kratkotrajnih izuzetaka. Uspostavljanjem adekvatne monetarne politike, ECB je uspešno ostvarila svoje ciljeve, u referentnom periodu, što je pokazano kroz rezultate trenda inflacije, monetarni agregat M3, kao i nivo kamatnih stopa.

\section{Ključne reči:}

monetarna politika, Evropska centralna banka, inflacija, kamatne stope, evro.

Received: November 13th, 2013. Correction: November 22nd, 2013. Accepted: January 17th, 2014. 